\title{
Genetic Exchange Between Oral Streptococci During Mixed Growth
}

\author{
By HOWARD K. KURAMITSU* AND VALERIE TRAPA \\ Deparment of Microbiology-Immunology', Northwestern Unirersity Medical-Dental Schools. \\ Chicago, IL 606II, USA
}

(Receited 3 Ma! 1984)

\begin{abstract}
To determine whether oral streptococci might exchange genetic information in the oral cavity. paired transformable strains of Streptococcus mutans. Streptococcus sanguis and Streptococtus milleri were grown together. Chromosomal and plasmid-borne antibiotic resistance markers could be readily transferred from $S$. mutans GS-5 to $S$. milleri NCTC 10707 or $S$. sanguis Challis during mixed growth. However, no exchange from the latter two organisms to strain GS-5 could be detected under these conditions. The transfer of genetic information from $S$. sanguis to $S$. milleri was also observed
\end{abstract}

\section{INTRODLCTION}

Human dental caries results from the acidogenic properties of micro-organisms present in dental plaque (Gibbons \& van Houte. 1975). Although primary attention has been focused on Sireptococcus murans in cariogenesis. other oral plaque streptococci such as Sireptococcus sanguis or Streptococcus milleri may also contribute to this disease process. As an adjunct to biochemical studies of these micro-organisms, more recent investigations have emphasized genetic approaches (Robeson et al., 1983: Perry ef al., 1983), and certain human oral isolates of $S$. mutans (Perry \& Kuramitsu, 1981), S. sanguis and $S$. milleri (Colman, 1969) have been transformed with homologous or heterologous DNA.

Since transformation of bacteria has been demonstrated after infection into animal hosts (Ottolenghi \& MacLeod, 1963), it is of interest to determine whether DNA could be exchanged between streptococci in the oral cavity. Chromosomal genetic markers have been exchanged between transformable strains of $S$. mutans, $S$. sanguis and $S$. milleri in ritro (Colman. 1969: Westergren \& Fmilson, 1977: Perry \& Kuramitsu, 1981). We have developed a model system to determine whether genetic exchange could occur between oral streptococci during growth in mixed culture. In this paper, the results from this system are discussed in regard to possible genetic exchange in the human oral cavity.

\section{METHODS}

Organisms. The human dental playue isolate S. mulams ( $S$ S-5 (serotype $c$ ) was maintained and routinely grown in Todd-Hewilt (Difco) medium as previously described (Kuramitsu. 1973). S milleri NCTC 10707 isolated from the human oral cavity was obtained from the National (ollection of Type (ultures (London. UK) and S. sanguis Challis, originally isolated from human serum. from D. Perry (Northwestern University. Chicago. Ill.. USA). All cultures were routinely transterred weekly into Todd-Hewitt medium. $S$. sanguis V7.36 containing the erythromycin-sesistance plasmid pVA736 was oblained from F. L. Macrina (Virginia Commonwealth University. Richmond. $V_{a}$. L $\left.S A\right)$ and $u$ as maintained in Todd-Hewilt medium containing erythromycin $(10 \mu \mathrm{g} \mathrm{ml} 1)$.

Antihiofic-ressstamt organisms. Mutants of the oral streptococci containing chromosomal streptomycin (Str) or rifampicin (Rif) resistance markers were isolated following nitrosoguanidine mutagenesis (Adelberg e't al., 1965). Fxponential-phase cells of each organism were mutagenized with nitrosoguanidine $\left(100 \mu \mathrm{g} \mathrm{m} \mathrm{l}^{-1}\right.$ ) for $30 \mathrm{~min}$ at $37 \mathrm{C}$. Washed with sterile saline to remove the mutagen, and grown in Todd-Hewitt broth for $18 \mathrm{~h}$ at $37 \mathrm{C}$. Samples of the cultures were then groun on Trypticase soy agar (Difco) piates in the anaerobic GasPak System (BBL.) containing either streptomycin $\left(2(0) \mu \mathrm{g} \mathrm{ml}^{-1}\right)$ or rifampicin $\left(10 \mu \mathrm{g} \mathrm{ml}^{-1}\right)$. Fach isolate was purified by restreaking and re-examined for transformability before being used in the mixed growth experiments. 
Plasmid pVA736, coding for erythromycin resistance (Eryr), was isolated from $S$. sanguis $V 736$ as previously described (Macrina et al., 1980). The purified plasmid was then introduced into both $S$. mutans GS-5 and S. milleri NCTC 10707 by transformation (Kuramitsu \& Long, 1982). The presence of plasmid pVA736 in the resultant transformants was verified following agarose gel electrophoresis of cleared lysates (Kuramitsu \& Long. 1982).

Transformation during mixed growth. Freshly grown inocula of each organism, approximately $8 \times 10^{\circ}$ c.f.u. were incubated separately and together in Todd-Hewitt broth $(5 \mathrm{ml})$ for $18 \mathrm{~h}$ at $37^{\circ} \mathrm{C}$. Samples $(0.1 \mathrm{ml})$ were then grown anaerobically for $48 \mathrm{~h}$ at $37^{\circ} \mathrm{C}$ on agar plates containing appropriate antibiotics to select for transfer of antibiotic resistance. Initial experiments indicated that $18 \mathrm{~h}$ incubation yielded approximately optimal yields of transformants during mixed growth. Differentiation between $S$. mutans and either $S$. sanguis or $S$. milleri in mixed culture was accomplished by using Mitis salivarius agar (Difco) plates. When $S$. milleri and $S$. sanguis were grown together, colonies were differentiated on the basis of the relative sensitivities of the two strains to the bacteriocin produced by $S$. murans GS-5 (S. sanguis Challis, but not $S$. milleri NCTC 10707, is sensitive to this bacteriocin). Isolated colonies were tested for bacteriocin sensitivity as described previously, by the soft agar overlay method (Paul \& Slade, 1975).

The frequency of transformation for each organism during mixed growth was calculated as the number of double antibiotic resistant mutants of each organism divided by the total number of each organism. Spontaneous mutation frequencies to antibiotic resistance were determined on antibiotic selection plates. Duplicate plates were prepared for each sample and the values represent the average of each pair. The data presented represent typical results from experiments repeated two to four times.

\section{RESULTS}

\section{Chromosome exchange between S. mutans and S. milleri}

To determine whether oral streptococci might exchange gene fragments by natural transformation during mixed growth, $S$. mutans GS-5, $S$. sanguis Challis, and $S$. milleri NCTC 10707 were selected as representative transformable human isolates of each species and grown in mixed culture. It was anticipated that some of the cells would lyse following growth in culture and release chromosomal DNA fragments which might subsequently transform heterologous cells in the same culture. In one group of experiments, $S$. mutans GS-5 (Rif") was grown with $S$. milleri NCTC 10707 (Str) and the production of Rif' Strr $S$. milleri and $S$. mutans cells was determined. The Rif phenotype from $S$. mutans was transformed into $S$. milleri during mixed growth (Table 1). The transformation frequency observed $\left(7.5 \times 10^{-6}\right)$ was almost two orders of magnitude higher than the spontaneous mutation rate of $S$. milleri $\left(\operatorname{Str}^{r}\right)$ to $\operatorname{Rir}^{r}(9.2 \times$ $10^{-8}$ ). The involvement of transformation was indicated by the complete elimination of double antibiotic-resistant mutants when DNAase was present during growth. In contrast to the results with $S$. milleri, no Str' Rif' $S$. mutans GS-5 colonies were detected. The lack of detectable transformation of strain GS-5 grown in mixed culture was not limited to the Rif strain since subsequent results (not shown) also demonstrated that the $\operatorname{Str}^{r}$ marker could not be transferred from $S$. milleri to another GS-5 strain containing plasmid pVA736.

\section{Genetic exchange between $S$. mutans and $S$. sanguis}

Since $S$. sanguis Challis has previously demonstrated relatively high in vitro transformation frequencies with chromosomal DNA from $S$. mutans GS-5 (Perry \& Kuramitsu, 1981), it was anticipated that streptococcal chromosomal markers might be readily transformed into these cells in mixed culture. Indeed, the Rif' marker from $S$. mutans GS-5 was transformed into $S$. sanguis Challis harbouring plasmid pVA736 during mixed growth (Table 2). However, no transfer of plasmid pVA736 from $S$. sanguis Challis into $S$. mutans GS-5 could be detected. Likewise, in a similar experiment the $\operatorname{Str}^{r}$ marker from $S$. sanguis Challis could not be transferred to $S$. mutans GS-5 during mixed growth (data not shown).

\section{Chromosomal transfer between $S$. sanguis and $S$. milleri}

Since S. sanguis Challis (Perry \& Kuramitsu, 1981) and S. milleri NCTC 10707 (Colman, 1969) exhibit relatively high in vitro transformation frequencies and both act as transformation recipients in mixed culture with $S$. mutans GS-5 (Tables 1 and 2), it was of interest to determine whether each acts as a recipient when the strains were grown together. When $S$. milleri $\left(\operatorname{Str}^{r}\right)$ was

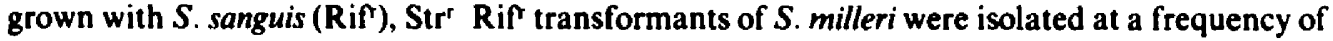
$2 \times 10^{-5}$, but no $\operatorname{Str}^{r} \operatorname{Rif}^{r} S$. sanguis transformants could be detected following growth. 
Table 1. Chromosomal transformation between $S$. mutans and $S$. milleri in mixed culture

S. mutans GS-5 (Rif ${ }^{r}$ ) and S. milleri NCTC 10707 (Str') were grown individually and together, as indicated, for $18 \mathrm{~h}$ at $37^{\circ} \mathrm{C}$ and mixed transformation was assessed as described in Methods. One mixed culture contained filter-sterilized DNAase $(24 \mu \mathrm{g} \mathrm{ml}-1)$ throughout the incubation period. Rifampicin $\left(10 \mu \mathrm{g} \mathrm{ml}^{-1}\right)$ and streptomycin $\left(200 \mu \mathrm{g} \mathrm{ml} \mathrm{m}^{-1}\right)$ were added to appropriate agar plates.

\begin{tabular}{|c|c|c|}
\hline \multirow[b]{2}{*}{ Bacteria } & \multicolumn{2}{|c|}{ Frequency of conversion of ${ }^{\bullet}$} \\
\hline & S. mutans to Str ${ }^{r}$ & S. milleri to Rif $\mathrm{r}$ \\
\hline $\begin{array}{l}\text { S. mulans GS-5 (Rif') } \\
\text { S. mutans GS-5 (Rif') + } \\
\text { S. milleri NCTC } 10707 \text { (Str) }\end{array}$ & $\begin{array}{l}<7.2 \times 10^{-8} \\
<2.1 \times 10^{-8}\end{array}$ & $7.5 \times 10^{-6}$ \\
\hline $\begin{array}{l}\text { S. mutans GS-5 (Rif') + } \\
\text { S. milleri NCTC } 10707\left(\text { Str }^{r}\right)+\text { DNAase }\end{array}$ & $<2.1 \times 10^{-8}$ & $<6.0 \times 10^{-}$ \\
\hline S. milleri NCTC 10707 (Str) & - & $9.2 \times 10^{-8}$ \\
\hline
\end{tabular}

- The frequency of conversion refers to spontaneous mutation rates for individual organisms, or transformation rates in mixed cultures.

Table 2. Genetic exchange between $S$. sanguis and $S$. mutans in mixed culture

S. mutans GS-5 (Rif ${ }^{r}$ ) and S. sanguis Challis (pVA 736) were grown together under standard conditions and treated as described in Methods using Mitis salivarius agar plates containing rifampicin $\left(10 \mu \mathrm{g} \mathrm{ml}^{-1}\right)$ and erythromycin $\left(10 \mu \mathrm{g} \mathrm{ml} \mathrm{m}^{-1}\right)$.

\begin{tabular}{|c|c|c|}
\hline \multirow[b]{2}{*}{ Bacteria } & \multicolumn{2}{|c|}{ Frequency of conversion of ${ }^{*}$} \\
\hline & S. mufans to Eryr & S. sanguis to $\mathrm{Rif}{ }^{\mathrm{r}}$ \\
\hline $\begin{array}{l}\text { S. mutans GS-5 (Rifr) } \\
\text { S. mutans GS-5 (Rifr) + } \\
\text { S. sanguis Challis (pVA736) }\end{array}$ & $\begin{array}{l}<7.8 \times 10^{-8} \\
<5.3 \times 10^{--}\end{array}$ & $3.6 \times 10^{-6}$ \\
\hline S. sanguis Challis (pVA736) & - & $9.7 \times 10^{-8}$ \\
\hline
\end{tabular}

\section{Plasmid exchange between oral streptococci}

Since cryptic plasmids have been demonstrated in some strains of oral streptococci (Macrina et al., 1977), it was of interest to determine whether plasmid transformation could be demonstrated in mixed culture. The Ery ${ }^{\top}$-coding plasmid pVA736 was chosen as a readily detectable indicator of plasmid exchange. This plasmid is composed of the naturally occurring Streptococcus ferus cryptic plasmid pVA380-1 ligated with a DNA fragment coding for Eryr isolated from another streptococcal plasmid, pVA1 (Macrina et al., 1980). Plasmid pVA736 can be readily transformed in titro into $S$. sanguis Challis (Macrina et al., 1980), S. mutans GS-5 (Kuramitsu \& Long, 1982), and $S$. milleri NCTC 10707 (H. K. Kuramitsu, unpublished results). When $S$. mutans GS-5 (pVA736) was grown with $S$. milleri $\left(\mathrm{Str}^{r}\right)$, transformation of the latter organism to Ery' was detected at a frequency of $5.8 \times 10^{-5}$. No transformation of $S$. mutans GS5 with the Str' chromosomal marker of $S$. milleri could be demonstrated in these experiments. Likewise, when $S$. mutans GS-5 containing pVA736 was grown with $S$. sanguis Challis, the plasmid was transferred at a frequency of $4.5 \times 10^{-7}$. In contrast, plasmid pVA736 could not be transferred to $S$. mutans GS-5 in mixed culture from either $S$. milleri (data not shown) or $S$. sanguis (Table 2). As with the chromosomal markers, plasmid pVA736 could also be transferred from $S$. sanguis Challis to $S$. milleri NCTC 10707 in mixed culture at a frequency of $2 \times 10^{-b}$, while no transfer in the reverse direction could be detected (data not shown).

\section{DISCUSSION}

The results of the present study indicate that no transformation of $S$. mutans GS-5 with chromosomal or plasmid-derived antibiotic resistance markers from either $\boldsymbol{S}$. sanguis Challis or S. milleri NCTC 10707 could be detected in mixed culture. However, both plasmid and chromosomal DNA derived from either organism can readily transform strain GS-5 when 
added in the standard in vitro transformation system (Perry \& Kuramitsu, 1981; Kuramitsu \& Long, 1982; H. K. Kuramitsu, unpublished results). The inability to demonstrate transformation of strain GS-5 is unlikely to be due to restriction or sequence specificity since no transformation could be detected when two GS-5 strains (GS-5 Str ${ }^{r}$ and GS-5 Rif') were grown together. Transformation of strain GS-5 depends on the development of competence, which is strictly dependent upon culture conditions as well as on the presence of serum (Perry \& Kuramitsu, 1981). It is therefore likely that the mixed culture environment we used was unsuitable for the development of competence in strain GS-5. In addition, the inability to transform GS-5 in mixed culture does not result from the antagonistic effects of either $S$. sanguis Challis or $S$. milleri NCTC 10707 since no inhibitory effects of the latter organisms on strain GS5 could be detected. Therefore, these results suggest that little or no transformation of $S$. mutans strains may occur in the human oral cavity.

In contrast to $S$. mutans GS-5, both plasmid and chromosomal transformation of $S$. sanguis Challis and $S$. milleri NCTC 10707 could be demonstrated in mixed cultures. Apparently the higher transformation frequencies demonstrated for these organisms under optimal conditions are sufficient to allow detection of transformation in mixed culture despite the non-ideal transformation conditions. If strains Challis and NCTC 10707 are representative of some strains of $S$. sanguis and $S$. milleri present in the human oral cavity, it is possible that some members of these species may undergo natural transformation in this habitat. However, since the model system of the present investigation is clearly distinct from that found in the oral cavity, implantation experiments in animal models would be necessary before the results reported here could be extrapolated to the situation in vivo.

We gratefully acknowledge the discussion and advice of D. Perry and F. L. Macrina during the course of this investigation. This study was supported by Public Health Service grant DE-03258 from the National Institute of Dental Research.

\section{REFERENCES}

Adelberg, E. A., Mandel, S. \& Chen, G. C. C. (1965). Optimal conditions for mutagenesis by $N$ methyl- $N$-nitrosoguanidine in Escherichia coli $\mathrm{K} / 2$. Biochemical and Biophysical Research Communications 8, 788-795.

Colman, G. (1969). Transformation of viridans-like streptococci. Journal of General Microbiology 57, 247-255.

Gibbons, R. J. \& van Houte, J. (1975). Dental caries. Annual Review of Medicine 26, 121-136.

KuRamrrsu, H. K. (1973). Characterization of invertase activity from cariogenic Streptococcus mutans. Journal of Bacteriology 115, 1003-1010.

Kuramitsu, H. K. \& Lono, C. M. (1982). Plasmidmediated transformation of Sireptococcus mutans. Infection and Immunity 36, 435-436.

Macrina, F. L., Reider, J. L., Virgili, S. S. \& Kopecko, D. J. (1977). Survey of the extrachromosomal gene pool of Streptococcus mutans. Infection and Immunity 17, 215-226.

Macrina, F. L., Jones, K. R. \& WoOd, P. H. (1980). Chimeric streptococcal plasmids and their use as molecular cloning vehicles in Streptococcus sanguis (Challis). Journal of Bacteriology 143, 1425-1435.
Ottolenghi, E. \& Macleod, C. M. (1963). Genetic transformation among living pneumococci in the mouse. Proceedings of the National Academy of Sciences of the Unired States of America 50, 417-419.

Paul, D. \& Slade, H. D. (1975). Production and properties of an extracellular bacteriocin from Streptococcus mutans bacteriocidal for group A and other streptococci. Infection and Immunity 12, 13751385.

Perry, D. \& Kuramitsu, H. K. (1981). Genetic transformation of Sireptococcus mutans. Infection and Immunity 32. 1295-1297.

Perry, D., Wondrack. L. M. \& Kuramitsu. H. K. (1983). Genetic transformation of putative cariogenic properties in Streptococcus mutans. Infection and Immunity 41, 722-727.

Robeson, J. P., Barletta, R. G. \& Curtiss III, R. (1983). Expression of a Streptococcus mutans glucosyltransferase gene in Escherichia coli. Journal of Bacteriology 153, 211-221.

Westergren, G. \& Emilon. G. C. (1977). Transformation of streptococci to streptomycin resistance by oral streptococcal DNA. Archives of Oral Biology 22. 533-537. 